\title{
Carbon Footprint and Production Costs Associated with Varying the Intensity of Production Practices During Field-grown Shrub Production
}

\author{
Charles R. Hall ${ }^{1,2,3}$ \\ Department of Horticultural Sciences, Texas A\&M University, 2133 TAMU, \\ College Station, TX 77843-2133
}

\author{
Dewayne L. Ingram ${ }^{1}$ \\ Department of Horticulture, University of Kentucky, N-318 Ag Science Center, \\ Lexington, KY 40546-0091
}

Additional index words. production costs, life cycle assessment, field-grown shrubs, carbon footprint

\begin{abstract}
This research uses a life cycle analysis and economic engineering approach to determine the costs and global warming potential (GWP) of production and postproduction practices associated with Taxus Xmedia 'Densiformis', which is often grown using a more capital-intensive regime during the propagative and harvesting stages than the typical field-grown shrub. Total variable costs incurred during the rooted cutting stage were slightly over $\$ \mathbf{\$ 0 . 2 4}$ per marketable rooted cutting. This was made up of \$0.1966, \$0.032, and \$0.0127 for labor, materials, and equipment operating costs, respectively. The GWP of materials and equipment used during the rooted cutting stage of production was 0.0097 and $0.2762 \mathrm{~kg} \mathrm{CO}$ equivalent $\left(\mathrm{CO}_{2} \mathrm{e}\right)$, respectively. Equipment costs in this phase were predominantly from heating the greenhouse $(92 \%)$ and the greenhouse heating functions comprised $95 \%$ of the rooting cutting GWP. GWP during the post-farm gate stage was $2.4506 \mathrm{~kg} \mathrm{CO} \mathrm{CO}_{2}$ per marketable shrub but was offset by $12.5522 \mathrm{~kg} \mathrm{CO}_{2}$ being sequestered in the shrub during its time in the landscape and weighted over the 100 -year assessment period, leaving a net GWP of $-8.1824 \mathrm{~kg} \mathrm{CO} \mathrm{C}_{2}$ e per marketable shrub by the end of the life cycle. Total takedown and disposal costs (labor) after an assumed 50-year life in the landscape were \$9.0610. During the entire life cycle from cutting to landscape to takedown and disposal, total variable costs incurred were $\$ 17.9856$ per shrub. These findings are consistent with previous studies in that the GWP is positive when considering the entire life cycle of the shrub from propagation to eventual removal from the landscape. Knowing the carbon footprint of production and distribution components of field-grown shrubs will help nursery managers understand the environmental costs associated with their respective systems and evaluate potential system modifications to reduce greenhouse gas (GHG) emissions.
\end{abstract}

Many current economic trends and driving forces point to the fact that the green industry is in a period of hypercompetitive rivalry with consumer demand exhibiting characteristics of being in the mature stage of the industry life cycle (Hall, 2010). Nonetheless, the green industry is a vital component of the economy in individual states and nationally, contributing $\$ 175.3$ billion in economic contributions (Hall and Dickson, 2011).

Received for publication 4 Dec. 2014. Accepted for publication 15 Jan. 2015.

This study was funded in part from a grant from The Horticulture Research Institute, Washington, DC.

Mention of a trademark, proprietary product, or vendor does not constitute a guarantee or warranty of the product by the authors and does not imply its approval to the exclusion of other products or vendors that also may be suitable.

${ }^{1}$ Professor.

${ }^{2}$ Ellison Chair in International Floriculture.

${ }^{3}$ To whom reprint requests should be addressed; e-mail c-hall@tamu.edu. et al., 2013; Hall and Dickson, 2011; Khachatryan et al., 2014; Yue et al., 2010, 2011).

Although it is widely recognized that landscape shrubs and trees and plants enhance property values (Behe et al., 2005; Stigarll and Elam, 2009), these plant materials also provide measurable and lasting environmental benefits. For example, ornamental shrubs and trees sequester carbon, reduce energy use, mitigate water runoff, clean the air, and provide a plethora of other ecosystems services (Netusil et al., 2014; Sagoff, 2009).

Recently, university researchers have quantified, using procedures first developed by Norris (2001), the value of a subset of these ecosystem services for trees (Hall and Ingram, 2014; Ingram, 2012, 2013; Ingram and Hall, 2013). However, only one study to date has focused specifically on these issues for the shrub category. Ingram and Hall (2014) looked specifically at the economic costs of component horticultural systems while conducting a life cycle assessment for a field-grown, deciduous shrub, Viburnum $\times j u d d i$, grown in the lower Midwest.

While exploring the same plant category, field-grown landscape shrubs, this research focuses on production and post-production practices associated with Taxus $\times$ media 'Densiformis', which is often grown using a different, more intensive regime during the propagative and harvesting stages than the typical field-grown shrub as discussed in Ingram and Hall (2014). Thus, one of the main contributions of this article to the literature is to document the added costs and the carbon footprint impact (and the inherent tradeoffs) associated with the more laborand energy-intensive activities on each end of the production continuum for the fieldgrown shrub plant category.

\section{Materials and Methods}

Life cycle assessment (LCA) is an approach that analyzes the flows associated with the whole life cycle of a product or a service, usually referred to as "cradle-tograve" (i.e., from raw material extraction, to manufacturing, use, recovery, and end-oflife). The first step in LCA is identifying the processes or steps for each stage in the life cycle. The inputs (materials and energy) and outputs (releases to air, water, soil, etc.) are determined for each step, evaluated for global warming potential, and summarized as the basis for drawing conclusions and improving future results (Ingram, 2012).

The carbon footprint of a product is a measure of all GHGs emitted in a product's life cycle and is measured in units of tons (or kg) of $\mathrm{CO}_{2} \mathrm{e}$. It is the impact indicator of primary interest to many stakeholders because it quantifies the GWP of a product or service. Because most GHGs are produced through burning fossil fuels, the carbon footprint of a product is primarily related to energy consumption (Ingram and Hall, 2013).

The primary GHG is $\mathrm{CO}_{2}$ and the GWP of any GHG is compared with the GWP of $\mathrm{CO}_{2}$, which is set at 1.0. Carbon dioxide evolution 
through such processes as burning fossil fuel has a negative impact and $\mathrm{CO}_{2}$ uptake or sequestration has a long-term positive impact on the atmosphere. A carbon footprint is expressed as the net pounds or kilograms of $\mathrm{CO}_{2}$ (or equivalence of other GHGs such as $\mathrm{CH}_{4}$ and $\mathrm{N}_{2} \mathrm{O}$ ) released per functional unit of the product.

This LCA study followed published standards of the International Organization for Standardization (ISO, 2006) and the PAS 2050 guidelines by British Standards Institution (BSI, 2011). Equipment use and input products were inventoried and their individual GHG emissions were determined, converted to $\mathrm{kg} \mathrm{CO}_{2} \mathrm{e}$ per functional unit, and summed. Emissions from the manufacturing of capital goods such as buildings and machinery were not included in this study as per PAS 2050, Section 6.4.4. Impact of land use change was not included in this study because it was assumed that the farms have been in agricultural production for at least 50 years and in nursery production for at least 20 years (Hodges et al., 2011). Other details regarding the economic engineering approach used to delineate input materials and equipment use are detailed in Ingram and Hall (2013), which also describes the Delphi method used to develop the model production systems of cultural practices of Midwestern growers.

The functional unit for this LCA study was a field-grown, hand-dug, 0.6-m Taxus $\times$ media 'Densiformis' with a $30-\mathrm{cm}$ (12-in) soil/rootball. The production system modeled consisted of taking cuttings from production plants in November, sticking them under mist in trays with individual cells, and rooting them using bottom heat in a polycarbonatecovered greenhouse. Ninety-five percent of the cuttings would be rooted successfully and transplanted to deep, 18-cell flats in July. They would be overwintered in a minimally heated poly house. A $1 \%$ shrinkage at this stage was assumed and the liners would be transplanted to the field the next August, 21 months after taking cuttings.

Inventory of inputs in rooted cutting production. Cuttings would be taken in November and stuck in 128-cell flats with a peat and perlite substrate. Seventy-five percent of the space in a $7.6 \times 30.5-\mathrm{m}$ permanentstructure greenhouse with a bilayer polycarbonate shell would be filled with 150,000 cuttings. This greenhouse was considered capital facilities and not included in the GWP assessment as per PAS2050 (BSI, 2011). Mist would be provided for 6 weeks. Plants would be irrigated as needed through that system from a municipal source. A $10{ }^{\circ} \mathrm{C}$ minimum air temperature would be maintained and bottom heat through Biotherm (TrueLeaf, Petaluma, CA) would maintain a $21{ }^{\circ} \mathrm{C}$ substrate temperature. It was assumed that 41,885 MJ of heat energy would be supplied by a natural gas furnace for the bottom heat. It was assumed that bottom heat would supply $52 \%$ of the energy required to maintain a $10{ }^{\circ} \mathrm{C}$ minimum air temperature based on an analysis by Biotherm. Heating the air would require $109,498 \mathrm{MJ}$ of heat energy December through May as calculated by Virtual Grower, a calculator for greenhouse heating requirements developed and maintained by the Agricultural Research Service, USDA (U.S. Department of Agriculture, Agricultural Research Service, 2014).

Contributions were overhead energy from gasoline for on-farm vehicles and electricity for buildings as previously published (Ingram and Hall, 2013) plus gas heat for a $20^{\prime} \times 50^{\prime} \times 12^{\prime}$ metal head house with R-13 insulation and maintained at a minimum of 10 ${ }^{\circ} \mathrm{C}$ for $8760 \mathrm{~h}$ per year. Heating the building would require $32,706 \mathrm{MJ}$, but it was assumed that the building served three greenhouses.

Inventory of inputs in liner production. In July, the rooted cuttings would be transplanted into deep-cell, 18-count flats and placed into a Quonset-type greenhouse with a double-layer, white polyethylene film covering at the rate of 83 per labor hour. Flat inserts $(0.12 \mathrm{~kg}$ each) would be used 1 year and trays $(0.14 \mathrm{~kg}$ each) would be cleaned ( $0.5 \mathrm{~min}$ of labor per flat) and re-used four times. Controlled-release fertilizer, $15 \mathrm{~N}-$ $3.9 \mathrm{P}-9.1 \mathrm{~K}$, would be broadcast at $50 \mathrm{~g} \cdot \mathrm{m}^{-2}$ and requiring $0.5 \mathrm{~h}$ of labor. This greenhouse was considered a temporary structure in terms of its GWP and variable costs for construction and would last 20 years. The metal frame would be constructed of galvanized steel pipe $(418 \mathrm{~kg})$ and would require 100 labor hours for construction. Stone $(36,000 \mathrm{~kg})$ was assumed on the greenhouse floor surface. The heat energy requirement to maintain a $4.4{ }^{\circ} \mathrm{C}$ minimum air temperature was calculated to be $52,733 \mathrm{MJ}$ by a forcedair system fueled by natural gas using the Virtual Grower software. Overhead energy use, including an increase for a functional head house serving three greenhouses, was assumed as described previously for rooting cutting production.

Inventory of inputs in field production. A fallow season would consist of two cover crops. The field would be plowed after fall harvest, disked, and sown with rye or wheat. The next spring, the cover crop would be turned in and field-disked and sown with buckwheat for the summer. Late summer, the buckwheat would be turned under and field-disked and leveled. Lime would be applied according to a soil test but assumed to be $4560 \mathrm{~kg} \cdot \mathrm{ha}^{-1}$. The field would be rotovated before transplanting liners into the field $(12,100$ per ha) using two tractors ( $24 \mathrm{hp}$ and $80 \mathrm{hp}$ ), a transplanter, and a wagon, 13,000 per day with an eight-person crew. Plants would be hand-watered immediately at $0.4 \mathrm{ha} \cdot \mathrm{d}^{-1}$ using a tractor with a tank and a two-person crew. Plants would be irrigated twice more the first season and once in subsequent years from surface water using a traveling gun for $6 \mathrm{~h} \cdot \mathrm{ha}^{-1}$.

Fertilizer $(20 \mathrm{~N}-2.2 \mathrm{P}-4.2 \mathrm{~K})$ would be banded in the row at $137 \mathrm{~kg}$ nitrogen/ha annually. Snapshot $2.5 \mathrm{~T}$ (2\% trifluralin + $0.5 \%$ isoxaben) (Dow AgroSciences LLC, Indianapolis, IN) would be applied the first year at $171 \mathrm{~kg}$ of product/ha. Years 2 to 5 , Pendulum (37.4\% pendimethalin) (BASF Corporation, Research Triangle, NC) would be applied twice per year as a tank mix alternating each year with Goal $(22.3 \%$ oxyflurfen; $5 \mathrm{~L}$ of product/ha) (Dow AgroSciences LLC) or Baracade (40.7\% prodiamine; $767 \mathrm{~mL}$ of product/ha) (Syngenta Crop Protection, LLC, Greensboro, NC).

The field would be cultivated twice per year, once when the fertilizer is banded before the first herbicide application as well as before the second herbicide application. Plants would be trimmed using a 25-hp tractor and finish mower in Years 2 through 4 and hand-pruned in Year 5 at 28 labor $h \cdot h^{-1}$. Hoeing would require 40 labor $\mathrm{h} \cdot \mathrm{ha}^{-1}$ performed twice annually.

Plants would be dug and balled by hand at $\$ 2.75$ each. A skid-steer would be used 41 $\mathrm{h} \cdot \mathrm{ha}^{-1}$ to load plants on the tractor/wagon and to transfer them to the truck for delivery. A tag would be secured to each plant when transferred from the wagon hauling plants to a truck.

Equipment use assumptions. The only equipment use for liner production was in constructing the Quonset greenhouse. Transport of the greenhouse components was included in the materials cost and GWP. A truck would haul the gravel for $40 \mathrm{~km}$ and spread it. The gravel surface would be further smoothed by hand.

Tractor power $(1 \mathrm{hp}=0.746 \mathrm{~kW})$ requirements for each function were determined through nursery manager interviews. The portion of maximum tractor throttle and load for each operation was assumed to be: land preparation, mowing fallow land, and hauling finished plants from the field, $59.6-\mathrm{kW}$ tractor at 0.85 throttle and 0.85 load; spraying/spreading in-row, between-row cultivation, and transporting liners to the field with a wagon, $18.6-\mathrm{kW}$ tractor at 0.50 throttle and 0.50 load; hauling the water tank for hand-watering, 40-hp tractor at 0.50 throttle and 0.50 load; transplanting liners, $29.8-\mathrm{kW}$ tractor at 0.85 throttle and 0.85 load; and moving harvested plants, $55.9-\mathrm{kW}$ skid-steer loader at 0.85 throttle and 0.85 load. A $37.3-\mathrm{kW}$ electric irrigation pump would be used during field production.

Postharvest activity assumptions. It was assumed that 300 finished shrubs would be transported to the customer on a flat-bed truck for a distance of $160 \mathrm{~km}$ and the truck would travel empty back to the nursery. The shrub would be transported to the landscape with a light truck and trailer as part of a 50-plant load traveling $32 \mathrm{~km}$. After 50 years of useful life, removal and disposal of the shrub after a 50 -year useful life would require $0.5 \mathrm{~h}$ of labor and 10 miles in a light truck.

Labor inputs. Although labor is obviously part of the cost of activities and processes, it does not contribute directly to the GWP of the product. The amount of labor for each operation was determined from nursery manager interviews and used to define the model. Labor requirements for operating equipment were calculated as 1.25 times the equipment operation hours to account for preparation and cleanup time.

Inventory analysis and data collection. The GWP of fertilizers, including $1 \%$ loss of nitrogen as $\mathrm{N}_{2} \mathrm{O}$, herbicides, substrates, seed for fallow season, \#9 gravel, irrigation system materials, white polyethylene film, and polypropylene for flats were determined from a variety of published sources as previously 
described (Ingram, 2013; Ingram and Hall, 2014; Koeser, 2013). Published diesel consumption standards for tractors at defined throttle and load (Grisso et al., 2010) were used for each operation as previously reported (Ingram, 2012). The "well-towheel" emission reported in GREET1_2011 (Vyas and Singh, 2011) as $2.9339 \mathrm{~kg} \mathrm{CO}_{2} \mathrm{e} / \mathrm{L}$ and $3.0153 \mathrm{~kg} \mathrm{CO} \mathrm{CO}_{2} \mathrm{e} / \mathrm{L}$ for gasoline and diesel, respectively, were used. The GWP of the galvanized tubing for Quonset-type greenhouse for liner production was determined to be $4.34 \mathrm{~kg} \mathrm{CO}_{2} \mathrm{e} / \mathrm{kg}$ (Simapro, Pre' North America, Inc., Washington, DC) as previously reported (Ingram and Hall, 2014). The GWP of natural gas combusted for heat in furnaces was greater than $100 \mathrm{Kw}$ in size was assumed to be $0.0817 \mathrm{GWP} / \mathrm{MJ}$ as published in SimaPro for North America.

The carbon dioxide sequestered during production was determined taking the average dry weight of three shrubs at harvest $(1.47 \mathrm{~kg})$ and calculating the sequestration $\left(2.693 \mathrm{~kg} \mathrm{CO}_{2}\right)$ required to produce that dry weight as previously published for trees and a deciduous shrub (Ingram, 2012, 2013; Ingram and Hall, 2014). The mature dry weight $(24 \mathrm{~kg})$ was estimated by using a previously described method using the regression of dry weight and plant volume index. A sigmoidal curve with a beginning value of $1.47 \mathrm{~kg}$, a maximum of $24 \mathrm{~kg}$ at 50 years, a midpoint of 20 years, and a 0.2 slope at the midpoint was used to model plant growth over the life of the plant in the landscape as previously reported (Ingram, 2012; Ingram and Hall, 2014). The impact on atmospheric
$\mathrm{CO}_{2}$ weighed over a 100 -year assessment period was calculated as previously published for trees using PAS 2050 protocols (BSI, 2011; Ingram, 2012, 2013; Ingram and Hall, 2014).

Fixed or overhead costs associated with buildings or other long-term assets (depreciation, interest, repairs, taxes, insurance, and other general overhead items such as management salaries) were not a part of this study because they may typically vary among nursery growers as a result of differences in each nursery firm's asset base (land, buildings, etc.). However, costs that some consider to be semifixed (or semivariable) in nature were included including electricity, natural gas, and gasoline for vehicles. These were included in the analysis because of their documented influence on GHG emissions (Ingram, 2013).

\section{Results and Discussion}

Total variable costs incurred during the rooted cutting stage were slightly over $\$ 0.24$ per marketable seedling. This was made up of \$0.1966, \$0.032, and \$0.0127 for labor, materials, and equipment operating costs, respectively (Table 1 ). These costs are necessarily small when expressed on a per-unit basis as a result of the high planting density of Taxus cuttings. However, they are much larger than those reported for a less intensive production system for Viburnum $\times j u d d i$ in Ingram and Hall (2014), mainly as a result of the heating costs associated with the propagation greenhouse.

Also included in Tables 1 through 4 are columns reflecting the GWP associated with the materials and equipment used while performing each cultural practice (labor constitutes no GWP). As stated earlier, GHG (primarily $\mathrm{CO}_{2}, \mathrm{~N}_{2} \mathrm{O}$, and $\mathrm{CH}_{4}$ ) are expressed in relation to the GWP potential of $\mathrm{CO}_{2}$ in a standard 100-year assessment period (Ingram, 2013) and are presented in kilograms $\mathrm{CO}_{2} \mathrm{e}$ as indicated in the first two columns of each table. The GWP of materials and equipment used during the rooted cutting stage of production was 0.0097 and $0.2762 \mathrm{~kg}$ $\mathrm{CO}_{2} \mathrm{e}$, respectively. Equipment costs in this phase were predominantly from heating the greenhouse $(92 \%)$; in fact, the greenhouse heating functions comprised $95 \%$ of the rooted cutting GWP.

The liner phase of the model production system involved taking the rooted cuttings produced and transplanting them in 18-cell trays and growing them out in a double-layer, polyethylene-covered hoophouse. Costs of $\$ 0.1386, \$ 0.3087$, and \$0.0119 were accumulated during the liner stage for labor, materials, and equipment use, respectively (Table 2). Most of the costs were incurred while transplanting the rooted cuttings and heating the hoophouse. Total costs for the entire propagation stages (rooted cutting and liner) amounted to $\$ 0.4592$ per marketable liner. The GWP associated with the rooted cutting and liner stages combined included $0.3245 \mathrm{~kg} \mathrm{CO}_{2} \mathrm{e}$ for materials and $0.2909 \mathrm{~kg}$ $\mathrm{CO}_{2} \mathrm{e}$ for equipment use.

The final phase, field production, represents the bulk of the costs and GWP incurred during the production of landscape-sized Taxus (Table 3). This is mainly because it is

Table 1. Costs and global warming potential (GWP) of labor, materials, and equipment use during rooted cutting production of Taxus $\times$ media 'Densiformis' in a propagation greenhouse.

\begin{tabular}{|c|c|c|c|c|c|c|c|c|c|}
\hline \multirow[b]{2}{*}{ Activity/components } & \multicolumn{3}{|c|}{ Materials } & \multicolumn{3}{|c|}{ Equipment use } & \multirow{2}{*}{$\frac{\text { Labor }}{\text { Costs }(\$)}$} & \multicolumn{2}{|l|}{ Total } \\
\hline & $\mathrm{kg}$ or unit/cutting & GWP $\left(\mathrm{kg} \mathrm{CO}_{2} \mathrm{e}\right)$ & Costs $(\$)$ & $\mathrm{H} /$ cutting & GWP $\left(\mathrm{kg} \mathrm{CO}_{2} \mathrm{e}\right)$ & Costs $(\$)$ & & $\overline{\mathrm{GWP}\left(\mathrm{kg} \mathrm{CO}_{2} \mathrm{e}\right)}$ & Costs $(\$)$ \\
\hline 128 -cell plug tray & 0.0001 & 0.0003 & 0.0034 & 0.0000 & 0.0000 & 0.0000 & 0.0000 & 0.0003 & 0.0034 \\
\hline Substrate & 0.0115 & 0.0091 & 0.0230 & 0.0000 & 0.0000 & 0.0000 & 0.0000 & 0.0091 & 0.0230 \\
\hline Fertilize, $15 \mathrm{~N}-9 \mathrm{P}-11 \mathrm{~K}$ & 0.0001 & 0.0001 & 0.0003 & 0.0000 & 0.0000 & 0.0000 & 0.0000 & 0.0001 & 0.0003 \\
\hline Mist and irrigation & 0.0000 & 0.0000 & 0.0000 & 0.0000 & 0.0000 & 0.0000 & 0.0053 & 0.0000 & 0.0053 \\
\hline Biotherm bottom heat & 0.0000 & 0.0002 & 0.0053 & 0.0000 & 0.2412 & 0.0104 & 0.0004 & 0.2415 & 0.0161 \\
\hline Total GWP and costs & & 0.0097 & 0.0320 & & 0.2762 & 0.0127 & 0.1966 & 0.2860 & 0.2412 \\
\hline
\end{tabular}

Table 2. Costs and global warming potential (GWP) of labor, materials, and equipment use during hoophouse production of Taxus $\times$ media 'Densiformis' liners.

\begin{tabular}{|c|c|c|c|c|c|c|c|c|c|}
\hline \multirow[b]{2}{*}{ Activity/components } & \multicolumn{3}{|c|}{ Materials } & \multicolumn{3}{|c|}{ Equipment use } & \multirow{2}{*}{$\frac{\text { Labor }}{\text { Costs }(\$)}$} & \multicolumn{2}{|l|}{ Total } \\
\hline & $\mathrm{kg}$ or unit/liner & GWP $\left(\mathrm{kg} \mathrm{CO}_{2} \mathrm{e}\right)$ & Costs $(\$)$ & $\mathrm{H} /$ liner & GWP $\left(\mathrm{kg} \mathrm{CO}_{2} \mathrm{e}\right)$ & Costs $(\$)$ & & $\overline{\mathrm{GWP}\left(\mathrm{kg} \mathrm{CO}_{2} \mathrm{e}\right)}$ & Costs $(\$)$ \\
\hline Polyethylene film & 0.0002 & 0.0005 & 0.0016 & 0.0000 & 0.0000 & 0.0000 & 0.0002 & 0.0005 & 0.0018 \\
\hline Trays for 18 -cell inserts & 0.0016 & 0.0041 & 0.0093 & 0.0000 & 0.0000 & 0.0000 & 0.0000 & 0.0041 & 0.0093 \\
\hline Substrate & 0.0113 & 0.0090 & 0.0001 & 0.0000 & 0.0000 & 0.0000 & 0.0000 & 0.0090 & 0.0001 \\
\hline Clean flats for re-use & 0.0000 & 0.0000 & 0.0000 & 0.0000 & 0.0000 & 0.0000 & 0.0007 & 0.0000 & 0.0007 \\
\hline Fertilize, $15 \mathrm{~N}-9 \mathrm{P}-11 \mathrm{~K}$ & 0.0000 & 0.0027 & 0.0002 & 0.0000 & 0.0000 & 0.0000 & 0.0000 & 0.0027 & 0.0003 \\
\hline Energy overhead & & & 0.0028 & & 0.0222 & 0.0003 & & 0.0222 & 0.0031 \\
\hline Total GWP and costs & & 0.3245 & 0.3087 & & 0.2909 & 0.0119 & 0.1386 & 0.6153 & 0.4592 \\
\hline
\end{tabular}




\begin{tabular}{|c|c|c|c|c|c|c|c|c|c|}
\hline \multirow[b]{2}{*}{ Activity/components } & \multicolumn{3}{|c|}{ Materials } & \multicolumn{3}{|c|}{ Equipment use } & \multirow{2}{*}{$\frac{\text { Labor }}{\text { Costs }(\$)}$} & \multicolumn{2}{|l|}{ Total } \\
\hline & $\mathrm{kg}$ or unit/shrub & GWP $\left(\mathrm{kg} \mathrm{CO}_{2} \mathrm{e}\right)$ & Costs $(\$)$ & $\mathrm{H} / \mathrm{shrub}$ & GWP $\left(\mathrm{kg} \mathrm{CO}_{2} \mathrm{e}\right)$ & Costs $(\$)$ & & $\mathrm{GWP}\left(\mathrm{kg} \mathrm{CO} \mathrm{CO}_{2} \mathrm{e}\right.$ & Costs $(\$)$ \\
\hline Plow 3 times & 0.0000 & 0.0000 & 0.0000 & 0.0006 & 0.0290 & 0.0194 & 0.0086 & 0.0290 & 0.0280 \\
\hline Sow rye & 0.0000 & 0.0028 & 0.0082 & 0.0003 & 0.0126 & 0.0060 & 0.0037 & 0.0154 & 0.0179 \\
\hline Disk 2 times & 0.0000 & 0.0000 & 0.0000 & 0.0002 & 0.0097 & 0.0048 & 0.0029 & 0.0097 & 0.0077 \\
\hline Lime application & 0.3703 & 0.2171 & 0.0082 & 0.0001 & 0.0048 & 0.0040 & 0.0014 & 0.2219 & 0.0136 \\
\hline Sow buckwheat & 0.0056 & 0.0041 & 0.0120 & 0.0003 & 0.0126 & 0.0060 & 0.0037 & 0.0167 & 0.0217 \\
\hline Disk & 0.0000 & 0.0000 & 0.0000 & 0.0001 & 0.0048 & 0.0024 & 0.0014 & 0.0048 & 0.0038 \\
\hline Rototilling & 0.0000 & 0.0000 & 0.0000 & 0.0002 & 0.0097 & 0.0059 & 0.0029 & 0.0097 & 0.0087 \\
\hline Transport liners to field & 0.0000 & 0.0000 & 0.0000 & 0.0001 & 0.0008 & 0.0015 & 0.0014 & 0.0008 & 0.0030 \\
\hline Transplant liners & 0.0000 & 0.6279 & 0.5352 & 0.0006 & 0.0145 & 0.0101 & 0.0566 & 0.6424 & 0.6019 \\
\hline Hand water & 0.0000 & 0.0000 & 0.0000 & 0.0012 & 0.0153 & 0.0160 & 0.0276 & 0.0153 & 0.0436 \\
\hline Irrigation - traveling gun & 0.0000 & 0.0000 & 0.0000 & 0.0031 & 0.0976 & 0.0058 & 0.0035 & 0.0976 & 0.0093 \\
\hline Apply fertilizer $(20 \mathrm{~N}-5 \mathrm{P}-5 \mathrm{~K})$ & 0.2777 & 0.4596 & 0.3673 & 0.0005 & 0.0039 & 0.0133 & 0.0072 & 0.4635 & 0.3878 \\
\hline Apply herbicides & 0.0223 & 0.0794 & 0.1771 & 0.0010 & 0.0077 & 0.0307 & 0.0144 & 0.0871 & 0.2222 \\
\hline Hoeing & 0.0000 & 0.0000 & 0.0000 & 0.0000 & 0.0000 & 0.0000 & 0.2946 & 0.0000 & 0.2946 \\
\hline Cultivate & 0.0000 & 0.0000 & 0.0000 & 0.0015 & 0.0116 & 0.0316 & 0.0216 & 0.0116 & 0.0532 \\
\hline Pruning & 0.0000 & 0.0000 & 0.0000 & 0.0005 & 0.0009 & 0.0054 & 0.0585 & 0.0009 & 0.0638 \\
\hline Harvest-contract & 0.0000 & 0.0000 & 0.0000 & 0.0000 & 0.0000 & 0.0000 & 2.7500 & 0.0000 & 2.7500 \\
\hline Tagging plants & 0.0000 & 0.0000 & 0.0175 & 0.0000 & 0.0000 & 0.0000 & 0.0752 & 0.0000 & 0.0927 \\
\hline Hauling from the field & 0.0000 & 0.0000 & 0.0000 & 0.0017 & 0.0395 & 0.0475 & 0.0235 & 0.0395 & 0.0710 \\
\hline Loading wagon and truck & 0.0000 & 0.0000 & 0.0000 & 0.0034 & 0.1633 & 0.0714 & 0.2707 & 0.1633 & 0.3421 \\
\hline Energy overhead & & & & & 0.2874 & 0.0496 & & 0.2874 & 0.0496 \\
\hline Total GWP and costs & & 1.3908 & 1.1255 & & 0.7257 & 0.3314 & 3.6294 & 2.1166 & 5.0863 \\
\hline \multirow{2}{*}{\multicolumn{4}{|c|}{$\begin{array}{l}\text { Weighted carbon sequestered during production } \\
\text { Net total GWP to farm gate }\end{array}$}} & & & & & -1.3465 & \\
\hline & & & & & & & & 0.7700 & \\
\hline
\end{tabular}

a 5-year process that is very labor- and equipment-intensive and the comparatively low population per hectare, which increases costs on a per-unit basis. A total of $\$ 5.0863$ (of farm gate costs) was spent performing all of the cultural practices necessary to produce a quality balled and burlapped 0.6-m shrub during the field production stage; thus, the total variable costs incurred from propagation to gate equaled $\$ 5.08$ per marketable shrub. The most expensive cultural practices included transplanting the liner, hoeing the fields, and loading and unloading activities (Fig. 1). Contract labor costs of $\$ 2.75$ per plant were also incurred. The GWP per shrub associated with the field production stage included $1.3908 \mathrm{~kg} \mathrm{CO}_{2} \mathrm{e}$ for materials and $0.7257 \mathrm{~kg} \mathrm{CO}_{2} \mathrm{e}$ for equipment use (Fig. 2) but was offset by $1.3465 \mathrm{CO}_{2}$ being sequestered in the shrub during production (weighted over a 100-year assessment period), leaving a net GWP of $0.77 \mathrm{~kg} \mathrm{CO}_{2}$ e per marketable shrub at this point in the life cycle (Fig. 3).

Total post-farm gate variable costs (Table 4) amounted to $\$ 3.83$ per marketable shrub, comprised of \$3.2309 for labor and \$0.6074 for equipment use, respectively. These included transporting the shrub to the landscaping company, transport to the landscape site, and transplanting the shrub in the landscape. Total GWP during the post-farm gate stage was $2.4506 \mathrm{~kg}$ $\mathrm{CO}_{2}$ e per marketable shrub, but was offset by $12.5522 \mathrm{CO}_{2}$ being sequestered in the shrub during its time in the landscape and weighted over the 100-year assessment period, leaving a net GWP of $-8.1824 \mathrm{~kg} \mathrm{CO}_{2} \mathrm{e}$ per marketable shrub by the end of the life cycle. Total takedown and disposal costs (labor) after an assumed 50-year life in the landscape were $\$ 9.0610$. During the entire life cycle from cutting to landscape to takedown and disposal,

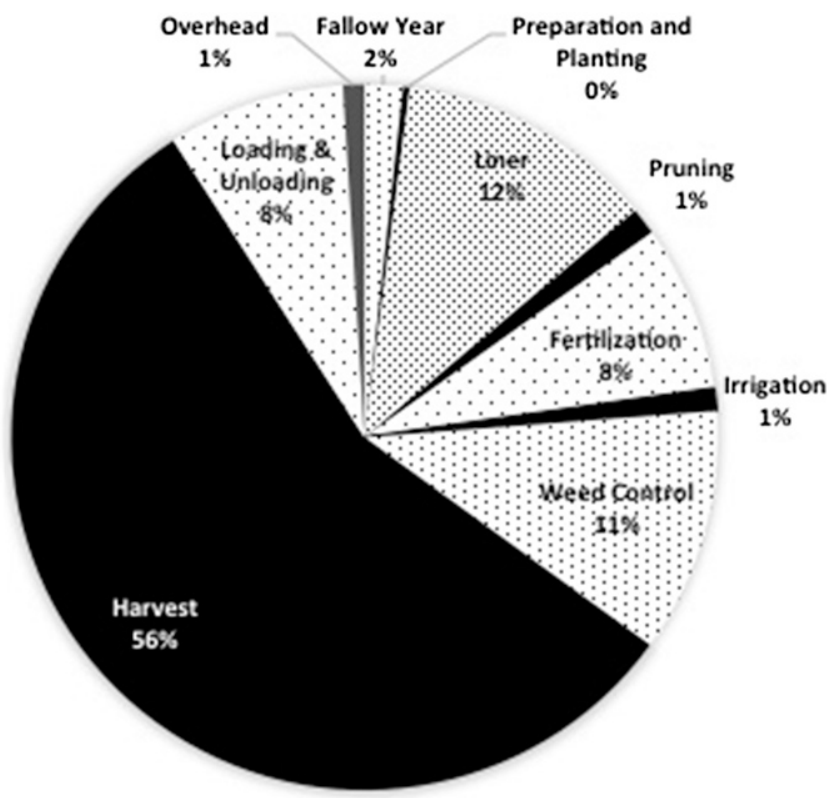

Fig. 1. Costs incurred during the field nursery production stage of Taxus $\times$ media 'Densiformis'.

total variable costs incurred were $\$ 17.9856$ per shrub.

An important feature of a modeling system using LCA within an economic engineering framework is the ability to determine the sensitivity of the system to impact possible production system component modifications. This is a useful tool in analyzing what-if scenarios that represent various tradeoffs that are important to nursery growers.

Labor is obviously a major component of the cost structure of any modeled nursery production system and is an ideal candidate for sensitivity analysis. In this model, the average 2013 Adverse Effect Wage Rate of $\$ 11.28$ for the Midwest was used in the study (U.S. Department of Labor, 2012). If the 90th percentile wage rate of $\$ 12.07$ for nursery and greenhouse farm workers as reported by the Bureau of Labor Statistics were used instead of the Adverse Effect Wage Rate, variable labor costs would have increased by $7 \%$. Total costs incurred during the entire life cycle would have risen from $\$ 17.99 /$ shrub to $\$ 18.71 /$ shrub. The sensitivity to the overall cost structure can also be applied to other types of increased labor expenses that are expected in the future (e.g., Affordable Care Act). 
Another area of concern in the environmental policy arena lies in the area of fertilizer use during the field production phase. If $25 \%$ more (less) fertilizer was used than the recommended rate, GWP would increase (decrease) by $0.1160 \mathrm{~kg} \mathrm{CO} \mathrm{CO}_{2} \mathrm{e}$ and $\$ 0.10$ would be added to (deducted from) the variable cost duction issues (e.g., weather) that delayed maturation of the crop and another growing season were required, the net effect would be of each marketable shrub. If there were pro-

another $0.1939 \mathrm{~kg} \mathrm{CO}_{2} \mathrm{e}$ would be incurred and another $\$ 0.22$ in variable costs would be added to the total cost of each shrub.

In this model, it was assumed that a natural gas furnace for the bottom heat in the greenhouse would supply 41,885 MJ of heat energy. More efficient heating systems such as geothermal heat pumps could reduce these fossil fuel requirements, thereby reducing the GWP associated with heating a greenhouse (Russo et al., 2014).

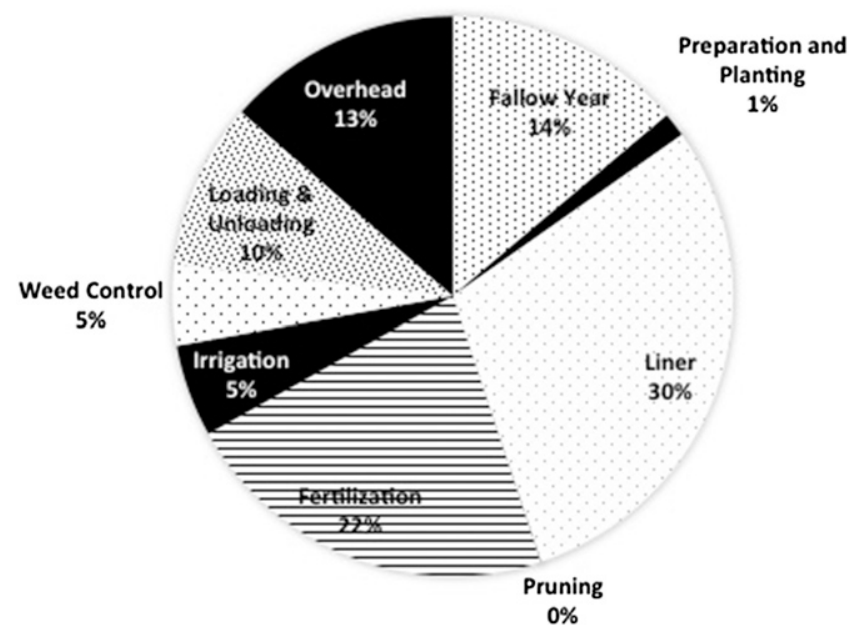

Fig. 2. Global warming potential incurred during the field production stage for Taxus $\times$ media 'Densiformis'.

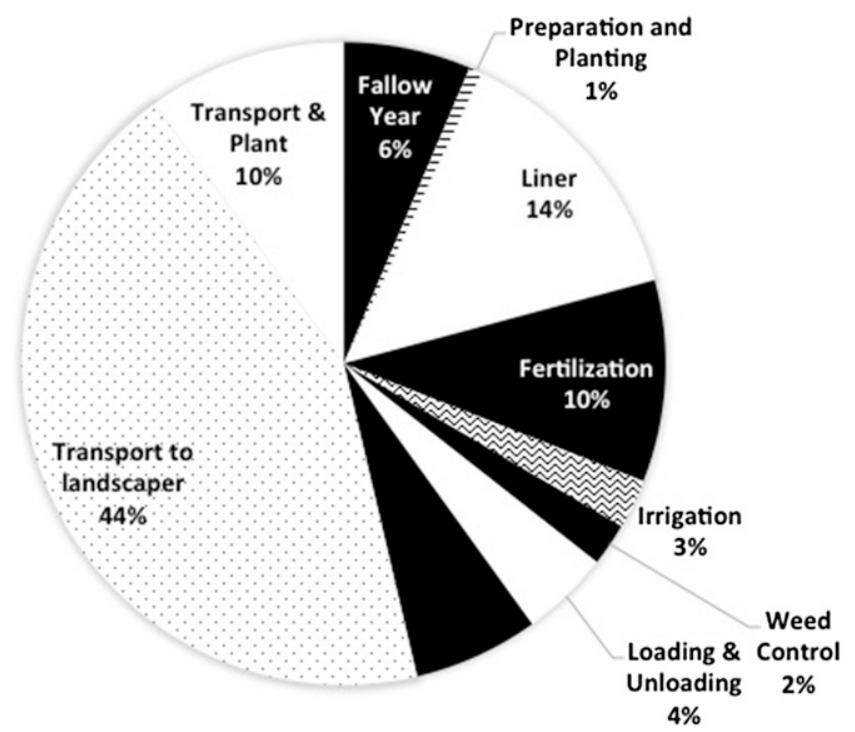

Fig. 3. Global warming potential incurred during the entire life cycle of Taxus $\times$ media 'Densiformis' from cutting to installation into the landscape.
The largest single contributor to cutting-tolandscape GWP and variable costs, however, was transportation from the nursery to the landscape service firm. It was assumed in this model that 300 finished shrubs would be transported to the customer on a flat-bed truck for a distance of $160 \mathrm{~km}$ and the truck would travel empty back to the nursery. If the distance to the landscaper were half $(80 \mathrm{~km})$, then GWP would be reduced by $0.9965 \mathrm{~kg} \mathrm{CO}_{2} \mathrm{e}$ and variable costs reduced by $\$ 0.32$ per shrub.

Another projected outcome from this study was to compare the highly intensive production system of this landscape shrub with other less intensive shrub production systems. Ingram and Hall (2014) report on the GWP and variable costs of Viburnum, which is representative of the less intensive propagation scenario, particularly in the propagation stage. In the less intense propagation model for Viburnum using no supplemental heating, Ingram and Hall (2014) reported rooted cutting costs of $\$ 0.11$ and a GWP of $0.036 \mathrm{~kg} \mathrm{CO}_{2} \mathrm{e}$. The propagation costs and GWP in the more intense Taxus model were $118 \%$ and $694 \%$ greater than for the Viburnum model, respectively. However, the rooted cutting only contributed $4.7 \%$ and $13.5 \%$ to the total costs and GHG emissions of the Taxus shrub at the farm gate.

When considering labor costs incurred during the field production stage for this model as compared with the Viburnum model described in Ingram and Hall (2014), we anticipated that most labor-related line items for the Taxus model during production in the field would be larger. This is indeed the case with the exception being the labor rates charged for digging. According to our industry sources, contracted digging rates for Taxus are $\$ 0.25$ lower ( $\$ 2.75$ per unit) than for Viburnum (\$3.00 per unit). Because of this, although all other costs are higher for Taxus, total variable costs incurred during field production are actually lower than for Viburnum. Growers should analyze these digging costs carefully, because according to the nursery growers involved in the project, they may even differ by state or region.

The other major difference between the two models was the labor costs associated with hauling the plants from the field to the loading area. For the Taxus model, the plants were loaded onto pallets and then loaded onto the wagon using a skid-steer and then hauled to the loading dock and onto a truck for delivery. In the Viburnum model, the plants were loaded by hand on a piece-rate basis

Table 4. Costs and global warming potential (GWP) of labor, materials, and equipment use during the postharvest and end-of-life stage of Taxus $\times$ media 'Densiformis'.

\begin{tabular}{|c|c|c|c|c|c|c|c|c|c|}
\hline \multirow[b]{2}{*}{ Activity/components } & \multicolumn{3}{|c|}{ Materials } & \multicolumn{3}{|c|}{ Equipment use } & \multirow{2}{*}{$\frac{\text { Labor }}{\text { Costs }(\$)}$} & \multicolumn{2}{|c|}{ Total } \\
\hline & $\mathrm{kg} / \mathrm{shrub}$ & $\operatorname{GWP}\left(\mathrm{kg} \mathrm{CO}_{2} \mathrm{e}\right)$ & Costs $(\$)$ & $\mathrm{H} /$ shrub & GWP $\left(\mathrm{kg} \mathrm{CO}_{2} \mathrm{e}\right)$ & Costs $(\$)$ & & $\mathrm{GWP}\left(\mathrm{kg} \mathrm{CO}_{2} \mathrm{e}\right)$ & Costs $(\$)$ \\
\hline Transport by landscaper & 0.0000 & 0.0000 & 0.000000 & 0.0000 & 0.4575 & 0.239500 & 0.140964 & 0.4575 & 0.380464 \\
\hline \multirow{3}{*}{\multicolumn{2}{|c|}{$\begin{array}{l}\text { Total postharvest costs } \\
\text { Total takedown and disposal costs } \\
\text { Total life cycle costs }\end{array}$}} & & & & 2.4506 & 0.6074 & 3.2309 & 2.4506 & 3.838273 \\
\hline & & & & & & & & 1.1491 & $\$ 9.0611$ \\
\hline & & & & & & & & & $\$ 17.9856$ \\
\hline
\end{tabular}


(\$0.35 per plant), which included hauling to the dock, where the plants were then loaded onto a truck by hand. Total variable costs associated with hauling and loading the plants were $\$ 0.4131$ for Taxus and $\$ 0.6681$ for Viburnum, demonstrating the tradeoff of substituting labor for mechanization for this cultural practice.

Finally, it is interesting to note that although the Taxus were propagated using the more capital-intensive (and higher GWP) greenhouse system than the Viburnum, because of the savings associated with digging, hauling, and loading the Taxus, they still have a lower life cycle cost per shrub (\$17.99 from cutting to grave) than the Viburnum (\$18.25 per shrub). Thus, growers should evaluate the use of technology very carefully in determining the potential efficiencies associated with these changes in cultural practices.

\section{Conclusions}

These findings are consistent with previous studies in that the GWP is positive when considering the entire life cycle of the shrub from propagation to eventual removal from the landscape (Ingram and Hall, 2014). From a supply standpoint, information gained from this cost analysis and LCA of fieldgrown ornamental shrub production systems will help managers better understand the economic dimensions of their production systems and associated cultural practices and help them better articulate an improved value proposition for their products in the green industry marketplace. From a demand standpoint, recent literature has demonstrated that consumers increasingly consider the potential environmental impact of green industry products (e.g., carbon footprint) when making purchasing decisions (Hall et al., 2010; Yue et al., 2010, 2011).

\section{Literature Cited}

Behe, B., J.D. Ben Campbell, C. Hall, R. Lopez, and C. Yue. 2013. Consumer preferences for local and sustainable plant characteristics. HortScience 48:209-215.
Behe, B., J. Hardy, S. Barton, J. Brooker, T. Fernandez, C. Hall, J. Hicks, R. Hinson, P. Knight, R. McNiel, T. Page, B. Rowe, C. Safley, and R. Schutzki. 2005. Landscape plant material, size, and design sophistication increase perceived home value. J. Environ. Hort. 23:127-133.

British Standards Institution. 2011. Specification for the assessment of the life cycle greenhouse gas emissions of goods and services. BSI British Standards (Publicly Available Specification) PAS 2050:2011. ISBN 9780580713828.

Evans, M.R. and D.L. Hensley. 2004. Plant growth in plastic, peat, and processed poultry feather fiber growing containers. HortScience 39:10121014.

Grisso, R., J. Perumpral, D. Vaughan, G. Roberson, and R. Pitman. 2010. Predicting tractor diesel fuel consumption. Virginia Cooperative Extension Publication 442-073.

Hall, C. 2010. Making cents of green industry economics. HortTechnology 20:832-835.

Hall, C.R., B.L. Campbell, B.K. Behe, C.Y. Yue, R.G. Lopez, and J.H. Dennis. 2010. The appeal of biodegradable packaging to floral consumers. HortScience 45:583-591.

Hall, C.R. and M.W. Dickson. 2011. Economic, environmental, and health/well-being benefits associated with green industry products and services: A review. J. Environ. Hort. 29:96103.

Hall, C.R. and D.L. Ingram. 2014. Production costs of field-grown Cercis canadensis L. 'Forest Pansy' identified during life cycle assessment analysis. HortScience 49:1-6.

Hodges, A.W., M.A. Palma, and C.R. Hall. 2011. Economic contributions of the green industry in the United States, 2007. HortTechnology 21:628-638.

Ingram, D.L. 2012. Life cycle assessment of a field-grown red maple tree to estimate its carbon footprint components. Intl. J.Life Cycle Assess. 17:453-462.

Ingram, D.L. 2013. Life Cycle Assessment to study the carbon footprint of system components for Colorado blue spruce field production and landscape use. J. Amer. Soc. Hort. Sci. 138:3-11.

Ingram, D.L. and C.R. Hall. 2013. Carbon footprint and related production costs of system components of a field-grown Cercis canadensis L. 'Forest Pansy' using life cycle assessment. J. Environ. Hort. 31:169-176.

Ingram, D.L. and C.R. Hall. 2014. Carbon footprint and related production costs of system components for a field-grown Viburnum $\times$ juddi using life cycle assessment. J. Environ. Hort. 32:175-181.
International Organization for Standardization. 2006. Life cycle assessment, requirements and guidelines. ISO Rule 14044:2006. 19 Aug. 2014. <https://www.iso.org/obp/ui/\#iso: std:iso:14044:ed-1:v1:en>.

Khachatryan, H., C. Yue, B.B. Ben Campbell, and C. Hall. 2014. The effects of consideration of future and immediate consequences on willingness to pay for eco-friendly plant attributes. J. Environ. Hort. 32:64-70.

Koeser, A.K. 2013. Performance and environmental impacts of biocontainers in horticultural production systems. PhD diss., Univ. of Illinois, Urbana-Champaign, IL. 19 Aug. 2014. <https:// ideals.illinois.edu/handle/2142/44332>

Netusil, N., Z. Levin, and V. Shandas. 2014. Valuing green infrastructure in Portland, Oregon. Landsc. Urban Plan. 124:14-21.

Norris, G.A. 2001. Integrating economic analysis into LCA. Environ. Qual. Mgt. 10:59-64.

Russo, G., A.S. Anifantis, G. Verdiani, and G.S Mugnozza. 2014. Environmental analysis of geothermal heat pump and LPG greenhouse heating systems. Biosys. Engr. 127:11-23.

Sagoff, M. 2009. The economic value of ecosystem services. Bioscience 59:461.

Stigarll, A. and E. Elam. 2009. Impact of improved landscape quality and tree cover on the price of single-family homes. J. Environ. Hort. 27:24-30.

U.S. Department of Labor. 2012. Wages in agriculture. 19 Aug. 2014. <http://www.dol.gov/ compliance/topics/wages-agricultural.htm $>$.

U.S. Department of Agriculture, Agricultural Research Service. Virtual Grower 3 model. 19 Aug. 2014. <http://ars.usda.gov/Research/docs. htm?docid $=22087>$.

Vyas, A. and M. Singh. 2011. GREET1_2011 (Greenhouse gases, related emissions, and energy use in transportation). Argonne National Lab., Chicago, IL. 19 Aug. 2014. <http://www. transportation.anl.gov/modeling_simulation/ VISION/>.

Yue, C.Y., J.H. Dennis, B.K. Behe, C.R. Hall, B.L. Campbell, and R.G. Lopez. 2011. Investigating consumer preference for organic, local, or sustainable plants. HortScience 46:610-615.

Yue, C.Y., C.R. Hall, B.K. Behe, B.L. Campbell, J.H. Dennis, and R.G. Lopez. 2010. Are consumers willing to pay more for biodegradable containers than for plastic ones? Evidence from hypothetical conjoint analysis and nonhypothetical experimental auctions. J. Agricultural and Applied Econ. 42:757772 . 